\title{
The role of SIRT3 in regulating cancer cell metabolism
}

\author{
Karina N Gonzalez Herrera ${ }^{1 *}$, Lydia W Finley ${ }^{3}$, Marcia C Haigis ${ }^{1,2}$ \\ From Metabolism, diet and disease \\ Washington, DC, USA. 29-31 May 2012
}

\section{Background}

Sirtuins are a family of $\mathrm{NAD}^{+}$-dependent deacetylase, deacylase, and/or mono-ADP ribosyltransferase enzymes involved in regulation of many biological processes. Mammals contain seven sirtuins, three of which are localized to the mitochondria (SIRT3-5). SIRT3 has been shown to be the major mitochondrial deacetylase that regulates metabolic enzymes and promotes oxidative metabolism and energy production. Loss of one copy of the SIRT3 gene is observed in various human cancers. Thus, we examined the role of SIRT3 in regulating metabolism in cancer cells.

\section{Materials and methods}

We have examined glucose uptake and lactate production in a variety of human cancer cell lines, as well as wild-type and SIRT3 null mouse embryonic fibroblasts (MEFs). In addition, we have utilized steady-state metabolomics to determine the metabolic profile of wild-type and SIRT3 null MEFs. Lastly, we utilized a combination of techniques, including quantitative RT-PCR and Western blotting, to examine the mechanism by which SIRT3 regulates cancer cell metabolism.

\section{Results}

Our data show that loss of SIRT3 increases glucose uptake and lactate production. Based on these and previous results from our laboratory, SIRT3 functions as a tumor suppressor to repress the Warburg effect by decreasing reactive oxygen species and destabilizing HIF1 $\alpha$ [1]. We are currently examining other metabolic pathways important to cancer that may be regulated by SIRT3.

${ }^{1}$ Department of Cell Biology, Harvard Medical School, Boston, MA 02115 USA

Full list of author information is available at the end of the article

\section{Conclusions}

In conclusion, we show that loss of SIRT3 results in increased glycolysis, which is the metabolic reprogramming observed in some cancer cells and is also known as the Warburg effect.

\section{Author details}

'Department of Cell Biology, Harvard Medical School, Boston, MA 02115, USA. ${ }^{2}$ The Paul F. Glenn Labs for the Biological Mechanisms of Aging, Harvard Medical School, Boston, MA 02115, USA. ${ }^{3}$ Cancer Biology and Genetics Program, Memorial Sloan-Kettering Cancer Center, New York, NY 10065, USA.

Published: 1 June 2012

\section{Reference}

1. Finley LWS, Carracedo A, Lee J, Souza A, Egia A, Zhang J, Teryua-Feldstein J, Moreira PI, Cardoso SM, Clish CB, Pandolfi PP, Haigis MC: SIRT3 opposes reprogramming of cancer cell metabolism through HIF1a destabilization. Cancer Cell 2011, 19:416-428.

doi:10.1186/1753-6561-6-S3-P18

Cite this article as: Gonzalez Herrera et al:: The role of SIRT3 in regulating cancer cell metabolism. BMC Proceedings 2012 6(Suppl 3):P18.
Submit your next manuscript to BioMed Central and take full advantage of:

- Convenient online submission

- Thorough peer review

- No space constraints or color figure charges

- Immediate publication on acceptance

- Inclusion in PubMed, CAS, Scopus and Google Scholar

- Research which is freely available for redistribution
() Biomed Central
() Biomed Cental 